\title{
Dampak Eksploitasi Anak Dalam Bidang Pendidikan
}

(Kasus Anak Penjual Asongan di Kota Palembang)

\author{
Azizah Husin, Muhammad Ajhie Guntara \\ Fakultas Keguruan dan Ilmu Pendididkan, Universitas Sriwijaya \\ Corresponding Author azizahhusin66@yahoo.co.id
}

\author{
Received: 26 April 2021; Revised: 16 July 2021; Accepted: 13 August 2021 \\ DOI: http://dx.doi.org/10.37905/aksara.7.3.947-958.2021
}

\begin{abstract}
Abstrak
Penelitian bertujuan untuk mengetahui dampak pendidikan pada anak yang tereksploitasi sebagai penjual asongan di kota Palembang. Penelitian ini menggunakan pendekatan kualitatif dengan analisa deskriptif. subjek penelitian menggunakan metode purposive sampling. Teknik pengumpulan data menggunakan teknik observasi dan wawancara. Hasil penelitian menunjukkan adanya penurunan nilai raport, penguasaan pengetahuan dasar yang kurang dan lemahnya pengetahuan umum. Selain itu, anak tidak mendapatkan pendidikan non formal pendidikan kesetaraan dan lainnya, serta terabaikannya pendidikan agama dalam hal ibadah, moral dan sopan santun dalam keluarga serta pendidikan sosialisasi dalam bermasyarakat.

Kata Kunci : Pendidikan, Exploitasi, Pedagang asongan
\end{abstract}

\begin{abstract}
This study aims to determine the impact of education on children who are exploited as hawkers in the city of Palembang. This study uses a qualitative approach with descriptive analysis. research subjects using purposive sampling method. Data collection techniques using observation and interview techniques. The results showed a decrease in the value of report cards, lack of mastery of basic knowledge and weak general knowledge. In addition, children do not get non-formal education, equality and other education, and religious education is neglected in terms of worship, morals and character in the family and socialization education in the community.
\end{abstract}

Keyword : Education, Exploitation, Hawker.

\section{PENDAHULUAN}

Anak merupakan generasi baru penerus cita-cita suatu bangsa dan sumber daya manusia bagi pembangunan nasional. Agar anak dapat menjadi generasi penerus bangsa, maka pemenuhan hak-hak anak sedari awal harus dipenuhi agar anak dapat tumbuh dan berkembang dengan baik. Menurut Keputusan Presiden No.36 tahun 1990, Setidaknya terdapat 10 hak anak yang harus dipenuhi baik oleh orang tua maupun negara, juga kesejahteraan anak harus dipastikan terpenuhi sebagaimana yang telah di atur dalam UU No. 4 tahun 1979 bahwa hak-hak yang telah diberi terhadap anak dapat menjamin pertumbuhan dan perkembangan anak dengan wajar baik secara rahasia, jasmaniah dan sosial. 
Peraturan Undang Undang No. 4 tahun 1979 memastikan bahwa orang tua dan negara memiliki kesadaran dan kewajiban dalam memenuhi hak-hak anak agar anak dapat tumbuh dan berkembang dengan baik. Walaupun Peraturan UUNo.4 tahun 1979 telah diterbitkan sebagai pengingat untuk orang tua dan negara, namun pada praktiknya tetap terdapat anak-anak yang tidak mendapat hak-hak sebagaimana Keputusan Presiden No.36 tahun 1990. Anak-anak yang tidak mendapat pemenuhan hak di latar belakangi berbagai motif. Kecil nya taraf penghasilan keluarga, kesempatan untuk mengeksploitasi anak, desakan ekonomi merupakan segilintir motif yang kadang muncul dalam keabsenan orang tua untuk memenuhi hak hak anak(Ayu:2016 dan Octariani:2016).

Keabsenan pemenuhan hak hak anak menyebabkan tuntutan baru bagi anak yaitu bekerja untuk memenuhi kebutuhan keluarga. Pada akhirnya anak akan ikut bekerja untuk memenuhi kebutuhan sehari hari sekalipun turun ke jalan untuk menjadi penjual asongan. perlakukan terhadap anak secara diskriminatif maupun sewenang-wenang oleh keluarga demi ke pentingan ekonomi, sosisal, maupun politik tanpa menghiraukan perkembangan fisik, psikis, dan status sosial anak merupakan suatu tindakan ekploitasi terhadap anak (Suharto, 2009). Berdasarkan Hasil penjaringan dinas sosial kota Palembang tahun 2017 terdata sebanyak 97 anak jalanan, 141 orang gelandangan, 50 orang pengemis, 37 orang pengamen, dan 73 orang gila dengan total 398 orang. 97 orang anak jalanan yang ditangkap memiliki pekerjaan sebagai pengamen, penjual tisu, jasa semir sepatu, manusia silver, hingga pengemis. Mereka bekerja di jalanan pada titik titik pusat kota seperti Simpang lampu Merah Charitas, lampu Merah Polda Kota Palembang, depan parkiran Mall Transmart Palembang, Kawasan Benteng Kuto Besak dari pagi siang hingga malam hari. Anak yang menjual asongan tersebut mengalami perlakuan ekploitasif.

Anak-anak yang terekploitasi dengan mencari nafkah dari pagi hingga malam tidak hanya mengalami perlakuan diskriminatif dari orang terdekat, namun juga rentan mengalami perlakuan diskriminatif lainnya dari orang orang di lingkungan dimana anak bekerja mencari nafkah (Cahyani:2018). Ekploitasi fisik maupun materi, keterlibatan kriminalitas, premanisme, penyalahgunaan obat obat terlarang hingga masalah pelecehan seksual merupakan salah satu celah eksploitasi yang mungkin anak terima selama bekerja di Kawasan jalanan (Beta:2013 dan Ratna:2004). Terlebih kondisi kehidupan anak yang hidup di jalanan jauh dari kata layak dan sejahtera. Anak-anak kehilangan hak untuk mengeyam bangku pendidikan, mendapat makanan yang bergizi, waktu bermain hingga rekreasi yang tersita(saleh:2016).

Menurut Undang Undang Perlindungan Anak No.23 tahun 2003 bahwa anak yang masih berada di bawah 18 tahun seharusnya anak yang masih memiliki hak untuk mengenyam pendidikan baik Pendidikan formal, non formal maupun informal. Bagi anak anak yang jalanan dengan motif desakan kebutuhan ekonomi tentu pendidikan formal tidak mungkin didapat dikarenaka ekploitasi waktu yang dilakukan untuk bersekolah dipakai untuk bekerja. Pada Pendidikan informal, penerimaan ajaran agama dan sopan santun mungkin sangat minim terabaikan oleh orang-orang terdekat seperti orang tua ataupun keluarga. Maka Pendidikan non formal merupakan salah satu pilihan bagi anak anak jalanan untuk merasakan edukasi dari satuan pendidikan.

Ekploitasi yang di alami anak secara langsung akan berdampak pada banyak aspek pendidikan. Aspek pendidikan formal, non formal maupun informal mungkin dapat terganggu. Namun lebih lanjut, dibutuhkan kajian mengenai dampak yang terjadi pada anak terkhususnya dampak pendidikan pada anak yang tereksploitasi sebagai penjual 
asongan. Berdasarkan permasalahan ekploitasi yang terjadi di Kawasan kota Palembang, maka peneliti akan melakukan penelitian mengenai dampak eksploitasi anak dalam bidang pendidikan (kasus anak penjual asongan di Kota Palembang) .

\section{METODE PENELITIAN}

Penelitian ini menggunakan metode kualitatif deskriptif. Data yang digunakan ialah data primer dan sekunder. Data primer di dapat dari subjek penelitian menggunakan metode wawancara dan observasi. Cakupan subjek dalam penelitian ditentukan dengan kriteria dimana terdapat dua kriteria utama yaitu (1) anak yang bekerja di jalanan melebihi batas wajar waktu kerja anak, dan (2) anak yang masih berstatus siswa di sekolah negeri di kota palembang. Peneliti melakukan pemilihan 5 subjek dengan teknik purposive. Setelah subjek didapat, maka wawancara terbuka dilakukan terhadap subjek untuk mendapatkan data primer. Data sekunder di dapat dari kantor dinas sosial serta jurnal dan artikel. Adapun instrumen indikator dalam penelitian ini, dijabarkan dalam tabel 1.

\begin{tabular}{|c|c|c|c|}
\hline No & Indikator & Deskriptor & Metode \\
\hline 1 & $\begin{array}{l}\text { Pendiikan Formal } \\
\text { (Sekolah) }\end{array}$ & $\begin{array}{l}\text { Untuk mengetahui dampak eksploitasi } \\
\text { terhadap pendidikan anak penjual asongan } \\
\text { dari pendidikan sekolah. } \\
\text { Dilihat dari: } \\
\text { a. Sekolah atau tidak } \\
\text { b. Nilai raport } \\
\text { c. Keaksaraan (Baca, tulis, hitung) } \\
\text { d. Pengetahuan umum (Hafal } \\
\text { Pancasila atau tidak, Hafal lagu } \\
\text { kebangsaan Indonesia Raya atau } \\
\text { tidak) } \\
\text { e. Keaktifan di Sekolah }\end{array}$ & $\begin{array}{l}\text { Wawancara } \\
\text { dan Observasi }\end{array}$ \\
\hline 2 & $\begin{array}{l}\text { Pendidikan Non- } \\
\text { Formal } \\
\text { (Masyarakat) }\end{array}$ & $\begin{array}{l}\text { Untuk mengetahui dampak eksploitasi } \\
\text { terhadap pendidikan anak penjual asongan } \\
\text { yang terjadi melalui pendidikan di } \\
\text { masyarakat dapat dilihat dari: } \\
\text { a. Keikutsertaan anak pada pendidikan } \\
\text { nonformal (Paket A, TPA/ TPQ, } \\
\text { Kursus, dan lainya) } \\
\text { b. Kegiatas positif yang anak ikuti. }\end{array}$ & $\begin{array}{l}\text { Wawancara } \\
\text { dan Observasi }\end{array}$ \\
\hline 3 & $\begin{array}{l}\text { Pendidikan } \\
\text { Informal } \\
\text { (Keluarga) }\end{array}$ & $\begin{array}{l}\text { Untuk mengetahui dampak eksploitasi } \\
\text { terhadap pendidikan anak penjual asongan } \\
\text { yang terjadi di dalam pendidikan keluarga } \\
\text { dapat dilihat dari: } \\
\text { a. Pendidikan Agama (Sholat \& } \\
\text { Mengaji) } \\
\text { b. Pendidikan Moral (Sopan santun) } \\
\text { c. Sosialisasi }\end{array}$ & $\begin{array}{l}\text { Wawancara } \\
\text { dan Observasi }\end{array}$ \\
\hline
\end{tabular}

Tabel 1. Indikator Penelitian 
Untuk pengolahan data, terdapat 3 tahapan yang dilakukan setelah data di dapat. Pertama, reduksi data untuk memilah informasi yang penting dari hasil wawancara terhadap subjek penelitian. Kedua, penyajian data yang berfungsi untuk menyajikan data menjadi lebih sistematik agar lebih mudah dibaca. Ketiga, verifikasi atau penarikan kesimpulan dengan memperhatikan data yang telah didapat. (Sugiyono:2019)

\section{HASIL PENELITIAN}

Berdasarkan wawancara \& observasi yang telah dilakukan terhadap 5 anak, diperoleh rincihan data 5 subjek dalam penelitian ini dan dijabarkan didalam table 2 .

\begin{tabular}{|c|c|c|c|c|c|}
\hline No & $\begin{array}{c}\text { Nama } \\
\text { anak }\end{array}$ & $\begin{array}{l}\text { Umur } \\
\text { (th) }\end{array}$ & Pendidikan & Pekerjaan & Lokasi \\
\hline 1 & RZ & 10 & $\begin{array}{l}\text { Putus } \\
\text { sekolah } \\
(2 \mathrm{SD})\end{array}$ & Penjual Masker & Pasar 16 ilir \\
\hline 2 & $\mathrm{CT}$ & 11 & $\begin{array}{l}\text { SDN } 8 \\
\text { Palembang } \\
- \text { Kelas } 5 \\
\text { SD }\end{array}$ & Penjual Kantong & Pasar 16 ilir \\
\hline 3 & RD & 12 & $\begin{array}{l}\text { SDN } 32 \\
\text { Palembang } \\
- \text { Kelas } 6 \\
\text { SD }\end{array}$ & $\begin{array}{l}\text { Penjual } \\
\text { Kemplang }\end{array}$ & Pusat perbelanjaan Transmart \\
\hline 4 & RH & 10 & $\begin{array}{l}\text { SDN } \quad 5 \\
\text { Palembang } \\
- \text { Kelas } 4 \\
\text { SD }\end{array}$ & Penjual Tisu & $\begin{array}{l}\text { Simpang } 4 \text { lampu merah } \\
\text { Radial }\end{array}$ \\
\hline 5 & AK & 13 & $\begin{array}{l}\text { SMPN } 31 \\
\text { Palembang } \\
- \text { Kelas } 1 \\
\text { SMP }\end{array}$ & Penjual Minuman & Pasar 16 ilir \\
\hline
\end{tabular}

Tabel 2. Subjek Penelitian

\section{Dampak Eksploitasi Anak Dalam Pendidikan Formal Sekolah atau Tidak}

Pada penelitian ini peneliti mengambil 5 orang subjek penelitian yang mana, Pertama subjek penelitian RZ saat ini berusia 10 tahun yang sudah putus sekolah sejak kelas 2 SD, Kedua subjek penelitian CT merupakan anak yang berusia 11 tahun dan saat ini masih bersekolah di SDN 8 Palembang kelas 5 SD, Ketiga subjek penelitian RD merupakan anak yang berusia 12 tahun dan saat ini RD masih bersekolah di SDN 32 Palembang kelas 6 SD, Keempat Subjek penelitian RH merupakan anak yang berusia 10 tahun dan saat ini RH Masih bersekolah di SDN 5 Palembang kelas 4 SD, kelima subjek penelitian AK merupakan anak yang berusia 13 tahun dan saat ini masih bersekolah di SMPN 31 Palembang kelas 1 SMP. 


\section{Nilai Raport}

Pada saat di lakukan wawancara mengenai Nilai raport kepada 4 Subjek penelitian yang masih bersekolah di dapati pada subjek penelitian CT nialai rapotnya dapat dikatakan buruk di karenakan banyaknya nilai Merah pada raportnya, dan untuk subjek penelitian RD beliau mengatakan hanya seperti itu itu saja, tidak baik tetapi juga tidak buruk dan RD mengatakan tidak pernah mendapat rengking di sekolah di karenakan sulit untu mengerti pelajaran, pasa subjek penelitian RH sama hal nya dengan penelitian RD bahwa nilai pelajaranya tidak baik tetapi juga tidak buruk, selanjutnya pada subjek penelitian AK beliau mengatakan bahwasanya nilai raport nya menurun di karenakan berjualan dan pada masa pandemi ini pelajaran di lakukan secara mandiri melalui daring.

Berdasarkan hasil tersebut, anak yang tereksploitasi cenderung memiliki performa nilai rapor yang buruk. Pada akhirnya, anak tidak dapat mempertahankan nilai pendidikan mereka seperti kondisi sebelum anak tereksploitasi sebagai penjual asongan.

\section{Kemampuan Aksara (baca, tulis, hitung)}

Pada saat di lakukan wawancara subjek penelitian di tes mengenai beberapa kemampuan dasar dan pengetahuan umum sesuai dengan tingkat pendidikan dan umumnya seperti kemampuan membaca menulis dan berhitung yang bertujuan untuk menilai kemampuan aksara yang mereka miliki, dan di dapati bahwasanya untuk kemampuan membaca dan menulis hampir semua subjek penelitian dampat membaca dan menulis dengan baik walaupun untuk beberapa anak di dapati tulisanya sulit untuk dibaca. Sedangkan ntuk kemampuan menghitung soal matematika sederhana yang penelitian berikan hanya 2 sampai 3 dari 5 soal yang dapat mereka kerjakan, hal itu dikarenakan kurangnya pemahaman anak mengenai soal yang di berikan. Dan untuk subjek RZ dikarenakan tidak lagi bersekolah maka RZ sama sekali tidak dapat menulis, membaca, bahkan menjawab soal matematika sederhana yang diberikan dengan benar.

Pada indikator kemampuan aksara, subjek penelitian tergolong memiliki skill cukup baik terlepas dari RZ yang tidak lagi bersekolah, dapat di lihat dari kemampuan menulis dan membaca walau untuk memahami soal matematika sederhana masih cukup sulit bagi mereka.

\section{Pengetahuan Umum}

untuk mengetahui pengetahuan umum yang subjek penelitian miliki, penelitian menanyakan tengang hafal atau tidak nya subjek penelitian dengan Pancasila dan lagu kebangsaan indonesia raya, dan setelan di lakukan wawancara didapatai, subjek penelitian RZ sama sekali tidak hafal dengan pancasila, dan sudah lupa dengan lagu Indonesia Raya. Untuk subjek penelitian CT sama hal nya dengan subjek RZ, subjek CT juga sudah lupa dengan pancasila, tetapi untuk lagu indonesia raya CT masih hafal dan bisa menyanyikanya. Selanjutnya untuk subjek penelitian RD beliau mengatakan suka terbalik balik untuk pelafalan pancasila dan untuk lagu Indonesia Raya Subjek RD masih hafal dengan lagu tersebut. Untuk subjek penelitian RH di dapati berbelit dan terbalik terbalik dalam pelafalan pancasila, dan untuk lagu indonesia raya RH masih hafal karena sering di nyanyikan dalam upacara di sekolah. Dan untuk subjek AK dia mengatakan untuk pancasila sila ke 4 terlalu panjang sehingga sulit untuk di ingat, dan untuk lagu Indonesia Raya AK masih hafal lagu tersebut. Pada idikator pengetahuan umum, subjek 


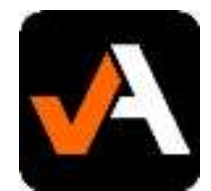

AKSARA: Jurnal Ilmu Pendidikan Nonformal

P-ISSN 2407-8018 E-ISSN 2721-7310 DOI prefix 10.37905

Volume 07, Issue 03 September 2021

http://ejurnal.pps.ung.ac.id/index.php/Aksara

memiliki pengetahuan umum yang rendah. Hal tersebut didasarkan pada tidak satupun dari mereka yang hafal pancasila, walaupun beberapa dari mereka masih menghafal lagu indonesia raya.

\section{Keaktifan Sekolah}

Pada masa pandemi seperti ini kegiatan persekolahan di lakukan secara online atau daring, setelah di lakukan wawancara dengan 4 orang subjek yang masih sekolah di dapati bahwasanya keaktifan mereka di sekolah kurang aktif karena mereka tidak langsung mengerjakan tugas yang di berikan oleh guru tapi menunggu sampai PR akan di kumpulkan pada hari selanjutnya. Untuk subjek penelitian AK dapat dikatakan cukup aktif, saat pelajaran mengguna aplikasi zoom AK menyenpatkan untuk hadir sebelum ia berjualan, tetapi untuk mengerjakan pr sama halnya dengan subjek penelitian lainya, AK baru mengerjakan PR saat aka di kumpul saja. Berdasarkan hasil penelitian, anak yang telah tereksploitasi sebagai penjual asongan cenderung memiliki penurunan dalam aktifitas sekolah.

\section{Dampak Eksploitasi Anak Dalam Pendidikan Non Formal Keikutsertaan dalam pendidikan non formal (Paket A, TPA/ TPQ, Kursus, dan lainya)}

Subjek RZ merupakan satu satunya subjek yang sudah putus sekolah dari kelas 2 $\mathrm{SD}$, tetapi untuk menunjang pendidikan nya tidak ada kegiatan nonformal yang dirinya ikuti. Bahkan orangtua pun tidak berfikir untuk mengikutsertakan RZ dalam kegiatan paket A, TPA/TPA ataupun kursus lainya. Untuk keempat subjek penelitian lainya saat di tanya dengan pertanyaan yang sama semua anak mengatakan bahwa mereka tidak sama sekali mengikuti kegiatan non formal lainya baik itu kursus mata pelajaran ataupun TPA/ $\mathrm{TPQ}$, adapun alasan dari jawaban dari para subjek penelitian adalah tidak adanya biaya untuk mengikuti kursus, ataupun hanya di paksa orang tua untuk berjualan setiap harinya.

Kurangnya pemahaman orang tua bahwasanya pendidikan nonformal juga penting bagi anak sebagai penambah pendidikan yang tidak anak dapatkan pada sekolah formal, bahkan pada masa pandemi seperti ini sekolah dilakukan kurang kondusif.

\section{Kegiatan Positif yang Diikuti}

selain kegiatan non formal seperti Paket A, TPQ/ TPA, Kursus, dan sebagainya yang berfungsi untuk mengembangkan potensi peserta didik dengan penekanan penguasaan pengetahuan dan keterampilan fungsional serta penembangan sikap dan kepribadian, ada kegiatan positif lainya yang dapat mengembangkan minat dan bakat anak. Saat wawancara bersama subjek penelitian di dapati bahwa, rata-rata dari mereka tidak mengikuti kegiatan positif apapun dikarenakan kurangnya waktu mereka untuk dapat mengikuti kegiatan tersebut dan hanya menghabiskan waktu untuk berjualan. Berdasarkan hasil tersebut, dipastikan bahwa anak yang tereksploitasi tidak mendapat pendidikan non formal baik TPA, TPQ, kursus, paket A atau kegiatan positif lainnya.

\section{Dampak Eksploitasi Anak Dalam Pendidikan Informal \\ Pendidikan Agama (Sholat \& Mengaji)}

Pendidikan informal adalah Pendidikan jalur keluarga dan kegiatan pembelajaran dilakukan secara mandiri oleh anggota keluarga dan lingkungan. Adapun contoh dari 
pendidikan informal berupa pendidikan agama, pendidikan moral dan pendidikan sosial. Berdasarkan hasil wawancara bersama dengan semua subjek penelitian mengenai pendidikan agama sholat dan mengaji didapati bahwa semua subjek tidak sama sekali di ajarkan untuk sholat atau bahkan mengaji, jangakan untuk mengajarkan, bahkan mengingatkan saja tidak di lakukan orang tua, dan tak banyak dari orang tua mereka tidak pernah juga melakukan sholat ataupun mengaji di rumah.

\section{Pendidikan Sopan santun}

Sebagai penjual asongan harus lah bagi mereka untuk bisa menawarkan barang dagangan dengan sopan dan santun agar calon pembeli tidak merasa risih dengan kehadiran para penjual asongan. Saat di lakukan wawancara tidak satupun anak mendapatkan pelajaran dari orang tua mengenai sopan santun dalam menawarkan barang dagangan, dan sekalinya di ajakan mereka di ajarkan untuk sedikit memaksa begitupun dengan subjek penelitian yang lainya mereka tidak di ajarkan bagaimana cara menawarkan dengan sopan. Dan saat di lakukan observasi mereka hanya menawarkan hanya seadanya dan tidak terlihat sama sekali tatakrama dalam menawarkan dagangan nya.

Berdasarkan hasil pengamatan, anak yang tereksploitasi sebagai penjual asongan tidak mendapatkan pendidikan moral yang cukup, sehingga menyebabkan sifat anak anak menjadi terkesan tidak memiliki sopan santun.

\section{Sosialisasi}

Dalam pengamatan yang di lakukan pada sosialisasi anak, di dapati subjek penelitian RZ terlihat buruk dalam bersosialisai sering mengejek teman nya dengan bahasa kasar yang kurang cocok untuk di ucapkan dengan teman temanya. Dalam pengamatan dengan subjek CT didapati CT acuh dengan teman saat temanya meminta bantuanya, dia hanya menggeleng dan pergi meninggalkan temanya, selanjutnya pada subjek RD terlihat dalam sosialisasi nya RD terbilang anak yang nakal, kurang sopan dengan temanya yang lebih tua, dan tidak akur dengan lingkunganya berjualan. Sedangkan subjek RH terlihat kasar dengan teman tidak segan menyakiti teman seperti yang terlihat dalam pengamatan RH menjahili temanya dengan mendorong temannya hingga terjatuh. Dan untuk subjek AK terlihat bahwa dia cenderung menutup diri untuk orang lain, kurang peduli dengan teman berjualanya dan terlalu fokus dengan dirinya sendiri. Berdasarkan indikator sosialisasi, pendidikan informal pada anak dalam hal bersosialisasi terabaikan oleh orang tua didasarkan pada pengamatan dan wawancara terhadap subjek.

\section{PEMBAHASAN}

\section{Dampak Eksploitasi Anak Dalam Bidang Pendidikan Formal}

Anak yang tereksploitasi sebagai penjual asongan memiliki dampak pada segi pendidikan formal. Dilihat dari perkembangan dan penilaian akhir berupa rapot disekolah, anak-anak tersebut mengalami penurunan. Orang tua mendidik anak-anaknya dengan cara yang keras yaitu dengan mempekerjakannya sebagai pedagang asongan dan menghadapkannya dengan bagaimana kerasnya kehidupan. Pada pengetahuan umum mereka yang cenderung tidak luas seperti anak pada umumnya, keaktifan dalam mengikuti kegiatan pendidikan menurun hingga anak berhenti mengeyam bangku 
pendidikan formal. Padahal pendidikan formal sangat diperlukan, karena pendidikan ini merupakan pendidikan yang paling umum diikuti oleh pelajar. Dengan mengikuti pendidikan formal, anak diharapkan mendapat pengetahuan awal untuk memasuki dunia kerja di masa mendatang, Namun, ada beberapa kasus dimana anak-anak terpaksa berhenti untuk sekolah formal, karena mereka dihadapkan dalam keadaan yang sulit dalam pemenuhan kebutuhan keluarga sehingga, adanya tekanan dari orang tua yang mengarah pada eksploitasi anak.

Adapun yang dimaksud dengan eksploitasi anak oleh orang tua atau pihak lainnya, yaitu menempatkan, membiarkan, melakukan, menyuruh melakukan, atau turut serta melakukan eksploitasi ekonomi. Meskipun di Indonesia telah ada undang-undang yang mengatur tentang perlindungan anak yaitu Undang-Undang No. 35 Tahun 2014 Tentang Perubahan Atas Undang-Undang No. 23 Tahun 2002 Perlindungan Anak namun masih banyak anak-anak yang mencari nafkah akibat eksploitasi dari orang tua.

Berbagai pekerjaan digeluti oleh anak yang bersekolah, putus sekolah, bahkan ada yang tidak sempat bersekolah. Padahal di usia anak, kebutuhan yang seharusnya dipenuhi oleh mereka adalah mendapatkan pendidikan dan juga mempunyai waktu yang cukup untuk bermain dalam masa perkembangan fisik dan mentalnya mendapatkan kasih sayang dari orangtua. Pada usia ini kemampuan fisik anak masih terbatas sesuai dengan pertumbuhannya. Sayangnya, dikarenakan faktor kemiskinan, mereka terpaksa bekerja (Suyanto, 2010; dan Itsnaini, 2015). Orang tua harus mengubah persepsi guna meningkatkan performa pendidikan formal anak. Agar anak dapat berkembang lebih lanjut, orang tua harus memberi kebebasan pada anak dalam memilih jalur pendidikannya. Pemberian kebebasan dimaksudkan agar anak memiliki kebebasan untuk mencari pengalamanya, karena pengalaman merupakan faktor yang penting bagi anak untuk menumbuhkan kapasitas dirinya seiring pertumbuhan usia(Novrinda,2017). Semakin banyak pengalaman yang anak dapatkan, maka anak akan semakin mengerti mengenai penilaian hal hal yang akan berguna bagi dirinya dan menciptakan kemandirian pada anak tersebut. Kemudian selama proses tersebut, orang tua hendaknya memberi sugesti posisif mengenai pencapaian yang telah anak raih baik pencapaian tersebut berupa hal baik maupun negatif guna stimulasi anak agar selalu giat dalam menempuh pendidikan formal. Memberikan, menyediakan, memfasilitasi serta mendukung pendididikan formal anak merupakan hal yang harus dilakukan berkelanjutan agar pendidikan anak dapat terus berkembang.

Faktor yang juga harus diperbaiki yaitu berasal dari dalam diri anak itu sendiri khususnya, jangan sampai sifat malas akan belajar mengundang orang tua untuk melakukan eksploitasi. Mereka harus menunjukan antusias dalam belajar kepada orang tua, selain itu perlu adanya dukungan serta bantuan dari pihak sekolah pada pendidikan formal. Seperti halnya penyediaan sarana dan prasarana belajar bagi anak yang tidak memilki handphone saat belajar online(Sunarto:2008). Apabila eksploitasi anak-anak ini terus berlarut, yang ditakutkan bahwa hal ini dapat mengabaikan hak-hak anak sehingga menyebabkan kerugian bagi anak-anak pedagang asongan baik dari segi pendidikan, kesehatan, psikis dan sosialnya.

\section{Dampak Eksploitasi Anak Dalam Bidang Pendidikan Non Formal}

Eksploitasi anak sebagai penjual asongan berdampak pada anak anak tidak mendapatkan pendidikan non formal sebagai mana mestinya. Kepentingan orang tua 
dalam memperkerjakan anak hingga ketidakpedulian orang tua terhadap informasi pendidikan non formal menyebabkan anak dibiarkan tidak mengikuti kegiatan pendidikan non formal seperti TPA, TPQ, kursus, paket A hingga kegiatan positif lainnya disela pertumbuhan mereka. Padahal Pendidikan non formal juga memiliki peranan penting, sebagai bagian sistem pendidikan nasional yang program programnya berkaitan dengan sektor pendidikan adalah wajar untuk memantapkan tugas pokoknya agar berorientasi pada perubahan masyarakat khususnya anak-anak yang akan memimpin masa depan.

Pendidikan non formal adalah jalur pendidikan di luar pendidikan formal yang dapat dilaksanakan secara terstruktur dan berjenjang. Mengacu pada Undang-Undang Nomor 20, Tahun 2003 tentang Sistem Pendidikan Nasional, Pasal 26, Ayat (6) menyatakan bahwa: Hasil pendidikan nonformal dapat dihargai setara dengan hasil program pendidikan formal setelah melalui proses penilaian penyetaraan oleh lembaga yang ditunjuk oleh Pemerintah atau Pemerintah Daerah dengan mengacu pada standar nasional pendidikan. Berdasarkan hasil observasi dan wawancara yang dilakukan penulis, anak yang tereksploitasi sebagai penjual asongan tidak ada yang mengikuti kelas non formal baik itu TPQ, TPA, Kursus, Paket A dan lainnya. Hal tersebut dikarenakan anakanak pedagang asongan tersebut melewatkan atau memanfaatkan sebagian besar waktunya untuk melakukan kegiatan sehari-hari di jalanan dan lingkungan pasar. Mereka kurang mendapatkan dukungan keluarga untuk pendidikan dan wajib memikul tanggung jawab keluarga dengan bekerja di jalanan sebagai pedagang asongan. Saat dirumah ia tidak lagi ada waktu untuk belajar dan bermain dengan teman-teman sebaya, karena sudah merasa lelah karena bekerja seharian.

Orang tua juga tidak mengetahui bahwa adanya Program pendidikan non formal yang diselenggarakan pemerintah maupun lembaga swadaya masyarakat (LSM). Padahal pendidikan non formal megajarkan pengembangan skill tententu seperti suatu keterampilan (softskill), keahlian, pembinaan, pengetahuan, dan sikap kepada pelajar guna membantu pelajar akan kebutuhan pendidikan, dengan harapan dapat dipergunakan semaksimal mungkin pada saat memasuki dunia kerja. faktor ketidaktahuan informasi tersebut kemudian yang menjadi salah satu faktor yang mempengaruhi anak tidak mendapatkan pendidikan formal.

Dalam hal ini, pendidikan non formal di Indonesia perlu mengembangkan potensi dengan, mempersiapkn peserta didik agar memiliki dan mengembangkan keterampilan, pengetahuan, sikap, nilai-nilai, dan aspirasi untuk dapat mengantisipasi kemungkinankemungkinan perubahan yang dapat terjadi di masa depan, dan kedua mengajarkan peserta didik agar mereka mampu beradaptasi terhadap orientasi kemajuan teknologi di era industri 4.0 guna membuka lebar peluang agar mencari pekerjaan di era kemajuan industri(Maenmunah:2018 dan Shaleh:2001). Pelaksanaan pendidikan non formal harus diikuti karena pendidikan di luar sekolah formal merupakan hal yang penting, menjadi mandiri, mempunyai cita-cita dan tujuan hidup. Perlu adanya upaya yang mampu untuk membuat pendidikan non formal berjalan efektif, salah satunya sebuah tempat atau rumah untuk anak-anak belajar atau bersinggah yang didalamnya diajarkan kegiatan-kegiatan yang berbasis pada pendidikan dan pemberian keterampilan bagi anak jalanan sehingga anak memiliki kemampuan yang lebih dalam bagi dirinya (Warsini:2005). Dalam hal ini peran aktif pemerintah sangatlah penting dimana pemerintah harus lebih memberikan perhatian kepada anak-anak yang putus sekolah dan anak-anak yang menonaktifkan 


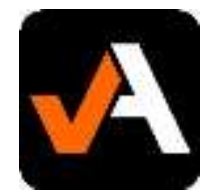

AKSARA: Jurnal Ilmu Pendidikan Nonformal

P-ISSN 2407-8018 E-ISSN 2721-7310 DOI prefix 10.37905

Volume 07, Issue 03 September 2021

http://ejurnal.pps.ung.ac.id/index.php/Aksara

sekolahnya dengan di era pandemic covid-19 melalui program-program serta kebijakan yang dibuat.

\section{Dampak Eksploitasi Anak Dalam Bidang Pendidikan Informal}

Eksploitasi sebagai penjual asongan menyebabkan anak tidak mendapat pendidikan informal dalam keluarga dengan baik. Baik pada pendidikan agama yang tidak diajarkan orang tua pada anak anak tersebut, pendidikan moral yang tidak ditanamkan dan diajarkan hingga pendidikan sosialisasi yang terabaikan. Pendidikan informal merupakan hal yang mendasar dan pertama yang yang paling mungkin anak harus dapatkan sebelum mereka mengeyam pendidikan formal dan non formal (Husin:2020).

Menurutut Undang-Undang NO 20 tahun 2003: 104 Tentang pendidikan Nasional menyatakan bahwa jalur pendidikan terdiri atas 3 jalur yaitu informal, formal, non formal dengan tujuan yang sama tetapi hanya berbeda sifat, ciri, dan penyelenggaraannya. Pendidikan informal merupakan pendidikan yang diperoleh dari keluarga. Pendidikan informal berjalan tanpa organisasi, yakni tanpa aturan yang kaku, tanpa evaluasi yang formal (Sudjana: 2006). Demikian pendidikan informal sangat penting dalam pembentukan kepribidian anak.

Hal ini diperkuat dengan UU Sisdiknas yang menyatakan bahwa pendidikan informal adalah jalur pendidikan keluarga dan lingkungan. Kegiatan pendidikan informal yang dilakukan oleh keluarga dan lingkungan berbentuk kegiatan belajar secara mandiri. Sedangkan menurut (Hidayat:2013), mengatakan orangtua adalah pendidik utama dan pertama dalam hal menanamkan keimanan bagi anaknya. Dari pernyataan ini menunjukan sudah sewajarnya orang tua menjadi pondasi dan tauladan utama bagi anak.

Namun pada prakteknya, anak-anak yang tereksploitasi sebagai pedagang asongan tidak semua anak mendapat pelajaran nilai moral kejujuran oleh orang tua. Begitupun pendidikan informal dari orang tua berupa pendidikan agama seperti mencontohkan sholat, pendidikan moral seperti kejujuran dan bersosialisasi seperti cara berinteraksi yang baik dengan orang lain juga minim dilakukan. Pendidikan informal tidak didapatkan dengan optimal dikarenakan kurangnya interaksi dengan orang tua disebabkan oleh lelahnya mencari nafkah. Selain itu kurangnya pengetahuan orang tua tentang pentingya sosialisasi anak dengan lingkungan yang baik.

Perlu adanya peranan orang tua yang optimal pada pendidikan informal dalam keluarga(Azizah: 2019). Meskipun tua belum bisa dipenuhi dengan baik, sebaiknya orang tua tidak mengeksploitasi atau memaksakan anak-anak untuk bekerja di jalanan. Dalam usia mereka yang masih belia ini, seharusnya anak-anak mendapatkan pendidikan yang cukup, mendapatkan kasih sayang serta arahan apa-apa saja yang boleh dan tidak boleh dilakukan sehingga mereka dapat mengoptimalkan potensi yang ada pada diri mereka.

\section{KESIMPULAN}

Berdasarkan hasil penelitian dan pembahasan yang telah di lakukan, eksploitasi anak sebagai penjual asongan di Kota Palembang berpengaruh pada proses pendidikan anak. Eksploitasi pada anak sebagai penjual asongan memiliki tiga dampak pada pendidikan anak. Pertama, pada pendidikan formal eksploitasi anak sebagai penjual asongan mempengaruhi penurunan nilai rapor, putus sekolah, belum menguasai baca tulis 
hitung dengan optimal, keaktifan di sekolah menurun serta penguasaan pengetahuan dasar yang kurang. Kedua, pada pendidikan non formal eksploitasi anak menyebabkan anak tidak mendapatkan pendidikan non formal seperti TPA, TPQ, paket A, kursus atau kegiatan positif lainnya disamping pendidikan formal yang diikuti. Ketiga, pengajaran mengenai ilmu dasar oleh keluarga pada anak menurun bahkan terabaikan seperti pendidikan nilai baik agama, moral maupun sosial.

\section{DAFTAR PUSTAKA}

Ayu, Nelsi Putri. 2016. Eksploitasi Orang Tua terhadap Anak (Studi: Pekerja Anak di Kelurahan Palinggam Kecamatan Padang Selatan, Kota Padang). Jurnal JIM STKIP Padang. Vol 1 No 1, 1-13.

Azizah Husin. 2019. Planting Values for Saving Groundwater through Family Education. Journal of Environmental Protection. vol 10 no 5 595-600

Azizah Husin, Yosef Yosef, Maria Elvira Asuan, Sri Sumarni, Portio O Surino, Carl O Dellomos. 2020. Entrepreneurship Education for Family Investment Values in Indonesia and the Philippines. Journal of Nonformal Education Vol 6. No 1, 1-8

Beta S. Iryani, D. S. Priyono. 2013. Eksploitasi Terhadap Anak Yang Bekerja di Indonesia. Jurnal Ekonomi dan Pembangunan Indonesia. Jakarta.

Cahyani, Atika Indah. 2018. Eksploitasi Anak Jalanan Sebagai Pengamen. Universitas Sriwijaya. Palembang.

Hidayat, Syarif. 2013. Pengaruh Kerjasama Orang Tua dan Guru Terhadap Disiplin Peserta Didik di Sekolah Menengah Pertama Negeri (SMP) Kecamatan JagakarsaJakarta Selatan. Jurnal Ilmiah Widya. 1(2) : 92-99

Maemunah. 2018 . Kebijakan Pendidikam Pada Era Revolusi Industri 4.0. Prosiding Seminar Nasional LPP Mandala. P-ISSN 2623-0291 E-ISSN 2623-2774

Novrinda, Dkk. 2017. Peran Orang Tua Dalam Pendidikan Anak Usia Dini Ditinjau Dari Latar Belakang Pendidikan. Jurnal Potensia Universitas Bengkulu. Vol 2 No 39-46

Octariani, A. Gayatri. 2014. Eksploitasi Pekerja Anak di Bawah Umur Sebagai Bentuk Penyimpangan Sosial : Studi Etnografi Anak Anak Pengumpul Koin di Dermaga Pelabuhan Merak, Kota Cilgeon. Universitas Pendidikan Indonesia. Banten.

Ratna, Dewi Agustin. 2004. Bentuk Eksploitasi Terhadap Anak Jalanan. Jakarta: Rinneka Cipta.

Saleh, Siful. 2016. Eksploitasi Pekerja Anak Pemulung. Jurnal Equilibrium Pendidikan Sosiologi. Universitas Muhamadiyah Makasar.

Sholeh, Soeaidy. 2001. Dasar Hukum Perlindungan Anak. Novindo Pustaka M Mandiri.

Sholihuddin, M. H. 2016. Eksploitasi dan Strategi Bertahan Hidup Anak Yang Menjadi Pengamen Jalanan.Universitas Airlangga.

Sudjana, Djudju (2006). Pendidikan Luar Sekolah: Wawasan Sejarah Perkembangan Falsafah \& Teori Pendudukung Azas. Bandung : Nusantara Press

Sugiyono. 2019. Metode Penelitian Kualitatif Untuk Penelitian Bersifat : Eksploratif, Enterpretif, Interaktif dan Konstruktif. Bandung : Alfabeta.

Suharto, Eko. 2009. Kemiskinan \& Perlindungan Sosial di Indonesia Menggagas Model Jaminan Sosial Universal Bidang Kesehatan. Bandung

Sunarto, Hartono. 2008. Perkembangan Peserta Didik. Jakarta: Rinneka Cipta.

Suyanto, Bagong. 2010. Masalah Sosial Anak.Jakarta: Kencana Pustaka. Undang Undang Perlindungan Anak (UU RI NO 23 tahun 2002) 


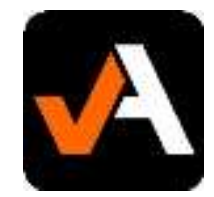

AKSARA: Jurnal Ilmu Pendidikan Nonformal

P-ISSN 2407-8018 E-ISSN 2721-7310 DOI prefix 10.37905

Volume 07, Issue 03 September 2021

http://ejurnal.pps.ung.ac.id/index.php/Aksara

Undang - Undang Hak - Hak Anak (KEPPRES No. 36 Tahun 1990)

Undang - Undang Kesejahteraan Anak (UU RI No 4 tahun 1979).

Warsini, dkk. 2005. Modul Penanganan Pekerja Anak. Departemen Tenaga Kerja dan Transmigrasi RI 